\title{
Whole genome characterization of non-tissue culture adapted HRSV strains in severely infected children
}

Rajni Kumaria ${ }^{1}$, Laxmi Ravi lyer ${ }^{2}$, Martin L Hibberd ${ }^{1,3}$, Eric AF Simões ${ }^{4}$ and Richard J Sugrue ${ }^{1,2^{*}}$

\begin{abstract}
Background: Human respiratory syncytial virus (HRSV) is the most important virus causing lower respiratory infection in young children. The complete genetic characterization of RSV clinical strains is a prerequisite for understanding HRSV infection in the clinical context. Current information about the genetic structure of the HRSV genome has largely been obtained using tissue culture adapted viruses. During tissue culture adaptation genetic changes can be introduced into the virus genome, which may obscure subtle variations in the genetic structure of different RSV strains.
\end{abstract}

Methods: In this study we describe a novel Sanger sequencing strategy which allowed the complete genetic characterisation of 14 clinical HRSV strains. The viruses were sequenced directly in the nasal washes of severely hospitalized children, and without prior passage of the viruses in tissue culture.

Results: The analysis of nucleotide sequences suggested that vRNA length is a variable factor among primary strains, while the phylogenetic analysis suggests selective pressure for change. The $\mathrm{G}$ gene showed the greatest sequence variation (2-6.4\%), while small hydrophobic protein and matrix genes were completely conserved across all clinical strains studied. A number of sequence changes in the F, L, M2-1 and M2-2 genes were observed that have not been described in laboratory isolates. The gene junction regions showed more sequence variability, and in particular the intergenic regions showed a highest level of sequence variation. Although the clinical strains grew slower than the HRSVA2 virus isolate in tissue culture, the HRSVA2 isolate and clinical strains formed similar virus structures such as virus filaments and inclusion bodies in infected cells; supporting the clinical relevance of these virus structures.

Conclusion: This is the first report to describe the complete genetic characterization of HRSV clinical strains that have been sequenced directly from clinical material. The presence of novel substitutions and deletions in the vRNA of clinical strains emphasize the importance of genomic characterization of non-tissue culture adapted primary strains.

Keywords: Human respiratory syncytial virus, HRSV A type severe clinical strains, Whole genome sequence, Phylogenetic analysis, Protein analysis

\section{Introduction}

Human respiratory syncytial virus (HRSV) is responsible for approximately 64 million infections and 160,000 deaths each year [1]. It is the most important cause of lower respiratory tract (LRT) infection in young children and neonates, and giving rise to a spectrum of

\footnotetext{
* Correspondence: rjsugrue@ntu.edu.sg

'Singapore-MIT Alliance for Research and Technology, Centre for Life

Sciences, \#05-06M, 28 Medical Drive, 117456, Singapore

Full list of author information is available at the end of the article
}

symptoms; from relatively mild to severe. Prior exposure to HRSV does not give complete protective immunity; re-infection occurs throughout life. Although HRSV infection is a major health concern in developed countries, it is a significant cause of ALRI-associated death in young children in developing countries [2]. There is currently no available vaccine, and the availability of specific antiviral drugs is limited.

The mature HRSV particle comprises a ribonucleoprotein (RNP) complex, formed by the interaction between

\section{Biomed Central}


the viral genomic RNA (vRNA), the nucleocapsid (N) protein, the phospo $(\mathrm{P})$ protein, and the large $(\mathrm{L})$ protein. The vRNA consists of ten contiguous genes, and each gene begins with a short non-coding region gene start (GS) sequence and ends with a gene end (GE) sequence. The first nine virus genes are separated by an additional coding sequence called the intergenic region, and the vRNA is flanked by a leader region at the 3' end, and a trailer region at the 5' end of the vRNA. Although the minimal functional polymerase activity requires an association between the $\mathrm{N}, \mathrm{P}$ and $\mathrm{L}$ proteins and the virus genome vRNA, additional viral proteins called the M2-1 protein, M2-2 and M protein regulate the activity of the polymerase [3-10]. The virus is surrounded by a lipid envelope in which the three virus integral membrane proteins are inserted. The G protein mediates attachment of the virus to the cell during virus entry [11], the fusion $(F)$ protein [12] mediates the fusion of the virus and host cell membranes during virus entry, while the role of the SH protein is currently unknown. In addition, two non-structural proteins called NS1 and NS2 are expressed, which are thought not to be present in the virus particle but play a role in countering the host innate immune response [13]. On the basis of antigenic differences primarily in the G gene, HRSV is divided into two main subtypes; HRSV A and HRSV B [14], which can be further subdivided into distinct lineages and genotypes based on the genetic diversity in G gene [15-18].

Molecular epidemiological studies of G gene suggest HRSVA predominates in most epidemics [17,19-24], but the association between HRSV subtype and severity of infection is uncertain The availability of complete genomic sequence information from HRSV field isolates is a prerequisite to understand the clinical basis of disease, and to better understand the biology of the virus in the clinical scenario. Currently, complete genome sequences are available only for four HRSVA strains (A2; GenBank accession number M74568, RSS-2; NC_001803, Long strain; AY911262 and Line 19; FJ614813) [25-30]. Moreover, these viral strains have been passaged in cell culture prior to genetic characterisation, which can lead to subtle genetic changes in the vRNA as a result of tissue culture adaptations. In this study, we present the indepth analysis of whole genome sequence of 14 HRSVA primary clinical strains. These viruses were sequenced directly from clinical material that was obtained from HRSV-infected patients, and without any prior passage of the viruses in tissue culture. This study provides the first detailed genome wide comparison of primary strains with the four cultured reference strains and reveals the rare and some new substitutions found exclusively in the primary strains only in F, L, M2-1 and M2-2 genes.

\section{Methods}

\section{Clinical Setting and Specimen Collection}

We conducted a prospective study of previously healthy term infants less than 1 year of age admitted to The Children's Hospital, Denver, Colorado, USA during three winter seasons; year 2003-2004, 2004-2005, and 2005-2006. Nasopharyngeal washings were collected from infants who were $\leq 1$ year of age at the time of enrolment into the study and screened for HRSV infection. Parents or legal guardian of the subject voluntarily signed informed consent. Patients having prior LRTI or documented wheezing disease; prior known RSV disease; diagnosis of BPD/CLD; congenital heart disease (except children with previous uncomplicated acyanotic CHD, e. g., PDA, small septal defect, who are anatomically and hemodynamically normal at the time of enrolment); mechanical ventilation (including CPAP) in the prior 6 months and known immunodeficiency were not included in this study. Ethical clearance for the study was obtained from the COMIRB of the University of Colorado, Denver.

\section{CDNA synthesis and PCR of complete RSVA genome}

Viral RNAs was extracted from $250 \mu$ l of the nasopharyngeal washings using the Trizol LS reagent (Invitrogen Life Technologies, USA), according to the manufacturer's instructions. A full length cDNA was synthesised using reverse primer P-15R (nucleotide position; nt 1519815222), based on reference strain HRSV A2 genome sequence. Briefly, $5 \mu \mathrm{l}$ of RNA was mixed with $1 \mu \mathrm{l}$ of 10 mM dNTPs, $1 \mu \mathrm{l}$ of $20 \mu \mathrm{M}$ reverse primer P-15R and $3 \mu \mathrm{l}$ RNase free water. Mixture was heated to $65^{\circ} \mathrm{C}$ for 5 minutes and incubated on ice for $1 \mathrm{~min}$ followed by addition of $4 \mu \mathrm{l}$ of 5X RT buffer, 200U of Superscript III reverse transcriptase (Invitrogen, USA), 40U of RNase-OUT RNase Inhibitor (Invitrogen, USA), $2 \mu \mathrm{l}$ of $25 \mathrm{mM} \mathrm{MgCl}_{2}$ and $2 \mu \mathrm{l}$ of $0.1 \mathrm{mM}$ DTT. The reaction was incubated at $50^{\circ} \mathrm{C}$ for $50 \mathrm{~min}$ and then heated at $85^{\circ} \mathrm{C}$ for $5 \mathrm{~min}$ to terminate the reaction. $1 \mu \mathrm{l}$ of RNase $\mathrm{H}$ was added per reaction tube and incubated at $37^{\circ} \mathrm{C}$ for $20 \mathrm{~min}$.

The viral genome was amplified as 15 overlapping PCR fragments covering the full length of this cDNA. Each of forward primer had M13/pUC (-20) primer and reverse primer having M13R-pUC(-26) primer sequence incorporated at its 5' end (Additional file 1 Table S1). Briefly, $1 \mu \mathrm{l}$ cDNA was added to PCR mixture containing $39.75 \mu \mathrm{l}$ of distilled water, $5 \mu \mathrm{l}$ of $10 \mathrm{X}$ PCR buffer, $1.25 \mu \mathrm{l}$ of $10 \mathrm{mM}$ dNTPs, $1 \mu \mathrm{l}$ each of $20 \mu \mathrm{M}$ forward and reverse primer and $1 \mathrm{U}$ of $p f u$ Ultra II fusion HS DNA polymerase (Stratagene, USA). Initial denaturation at $95^{\circ} \mathrm{C}$ for $1 \mathrm{~min}$ was followed by 40 cycles of PCR with each cycle of denaturation for $20 \mathrm{sec}$ at $95^{\circ} \mathrm{C}$, annealing for $20 \mathrm{sec}$ at $55^{\circ} \mathrm{C}$ and elongation for $45 \mathrm{sec}$ at $72^{\circ} \mathrm{C}$, with a final extension cycle of $5 \mathrm{~min}$ at $72^{\circ} \mathrm{C}$. 
The PCR products were separated by electrophoresis using $1 \%$ agarose gel and visualized using $1 \mathrm{X}$ GelRed (Biotium, CA).

\section{DNA sequencing}

PCR products were purified and nucleotide sequencing was performed on both forward and reverse strands of each fragment using ABI Big Dye Terminator v3.1 Reaction kit (Applied Biosystems, USA) and analysed using ABI 3730XL DNA Sequencer (Applied Biosystems, USA). As in every PCR product, the $5^{\prime}$ end of forward strand had M13/ pUC $(-20)$ primer sequence and the 5 'end of its reverse strand had M13R-pUC(-26) primer sequence, thus sequencing of the forward and reverse strands of all the PCR fragments was carried out using M13/pUC (-20) primer and M13R-pUC(-26) primer respectively. In addition, a set of internal forward and reverse sequencing primers were designed and used for each fragment to obtain complete 2 fold sequencing coverage (primer sequences available on request). The 3' end terminal region of genome was sequenced with help of reverse primer RSVSTART- (primer binding position nt 341-322, which is in the NS1 gene), which moves towards 3 ' end of genome till nucleotide 1 (start of genome). While the 5' end of the genome was sequenced with help of primer RSVEND (primer binding position nt 14917-14938, in the L gene), which covered the sequence till 5' end of the genome. (primer sequences available on request). The strategy of amplification and sequencing was first standardized using RSVA2 lab strain before its adaptation for clinical strains. The fourteen HRSVA genome sequences have been deposited into GenBank [Accession numbers GU591758- GU591771].

\section{Phylogenetic analysis}

The nucleotide sequences were mapped to HRSVA2 reference strain using Seqscape software 2.5 (Applied Biosystems, USA) and resultant consensus sequences were used for phylogenetic analysis using MEGA 4.0.2 and CLUSTAL W software. The published complete nucleotide sequences of all the four cultured HRSV A strains: A2 (GenBank accession numbers M74568), RSS2 (NC_001803), Long (AY911262), Line 19 (FJ614813) and one HRSV B reference strain 9320 (AY353550) were downloaded from NCBI GenBank for comparison. Phylogenetic tree was estimated by Neighbor-joining (NJ) method[31]. The evolutionary distances were computed using the Maximum Composite Likelihood method [32]. The statistical robustness and reliability of the branching order within the phylogenetic tree were confirmed through a bootstrap analysis using 1,000 replicates for the NJ tree $[32,33]$. EMBOSS Transeq (EMBOSS EBI), an online bioinformatics translation tool was used for translation of the nucleotide sequences of genes to protein sequences.

\section{Immunofluorescence microscopy}

Cells were labeled as described previously [34]. Briefly, cells on $13 \mathrm{~mm}$ glass cover slips were generally fixed with $3 \%$ paraformaldehyde in PBS for $30 \mathrm{~min}$ at $4{ }^{\circ} \mathrm{C}$, permeabilised using $0.1 \%$ saponin, and then labeled with primary antibodies anti-RSV (Novocastra; Anti-RSV composite antibody preparation, which recognizes the N, P, M2-1 and F proteins,) and a secondary antibody conjugated to FITC. The stained cells were mounted on slides using Citifluor ${ }^{\mathrm{TM}}$ and visualized using a Nikon eclipse 80i fluorescence microscope.

\section{Results and Discussion}

\section{Strategy developed for HRSVA whole genome} amplification and nucleotide sequencing

Although complete genomic sequence has been reported for RSVA2, RSS, long and Line 19 virus isolates [25,27-30], the viruses were passaged in tissue culture prior to sequencing the vRNA. In this current report we present the first complete genetic characterisation of HRSVA clinical strains, obtained directly from patient specimens without prior passage of the viruses in tissue culture. This avoided the acquisition of genetic changes due to tissue culture adaptation, and enabled us to detect subtle sequence variations in the vRNA of these viruses, changes that could in principle be confused with genetic changes that arise from tissue culture adaptations. We adopted a simple approach for sequencing of vRNA in clinical specimens that circumvented the need for prior growth in tissue culture. A major advantage of this methodology is that complete vRNA sequence information can be obtained from clinical specimens even when the vRNA is low (e. g due to low viral load), and in cases where the virus strains can't be recovered even by growth in tissue culture.

The genome wide sequence analysis was conducted on fourteen primary HRSVA strains isolated from hospitalized children with severe HRSV infection (referred to as RSV-1 to RSV-14). The strategy for the nucleotide sequencing of the vRNA generated 15 overlapping PCR products, which covered the entire virus genome length This experimental strategy enabled us to produce high concentration of specific DNA products for all the fifteen fragments from each of the clinical strains. (Figure 1A). A full genome length single stranded cDNA representing the vRNA was synthesized by using reverse primer ( $\mathrm{P}-15 \mathrm{R})$ that binds at the 5 'end of the vRNA till the last nucleotide of genome. This cDNA was sufficient for formation of all the fifteen PCR fragments using fragment specific primers (Figure 1B). As the first forward primer (P-1F) binds to the first nucleotide of the genome and the fifteenth reverse primer $(\mathrm{P}-15 \mathrm{R})$ binds till the last nucleotide at 


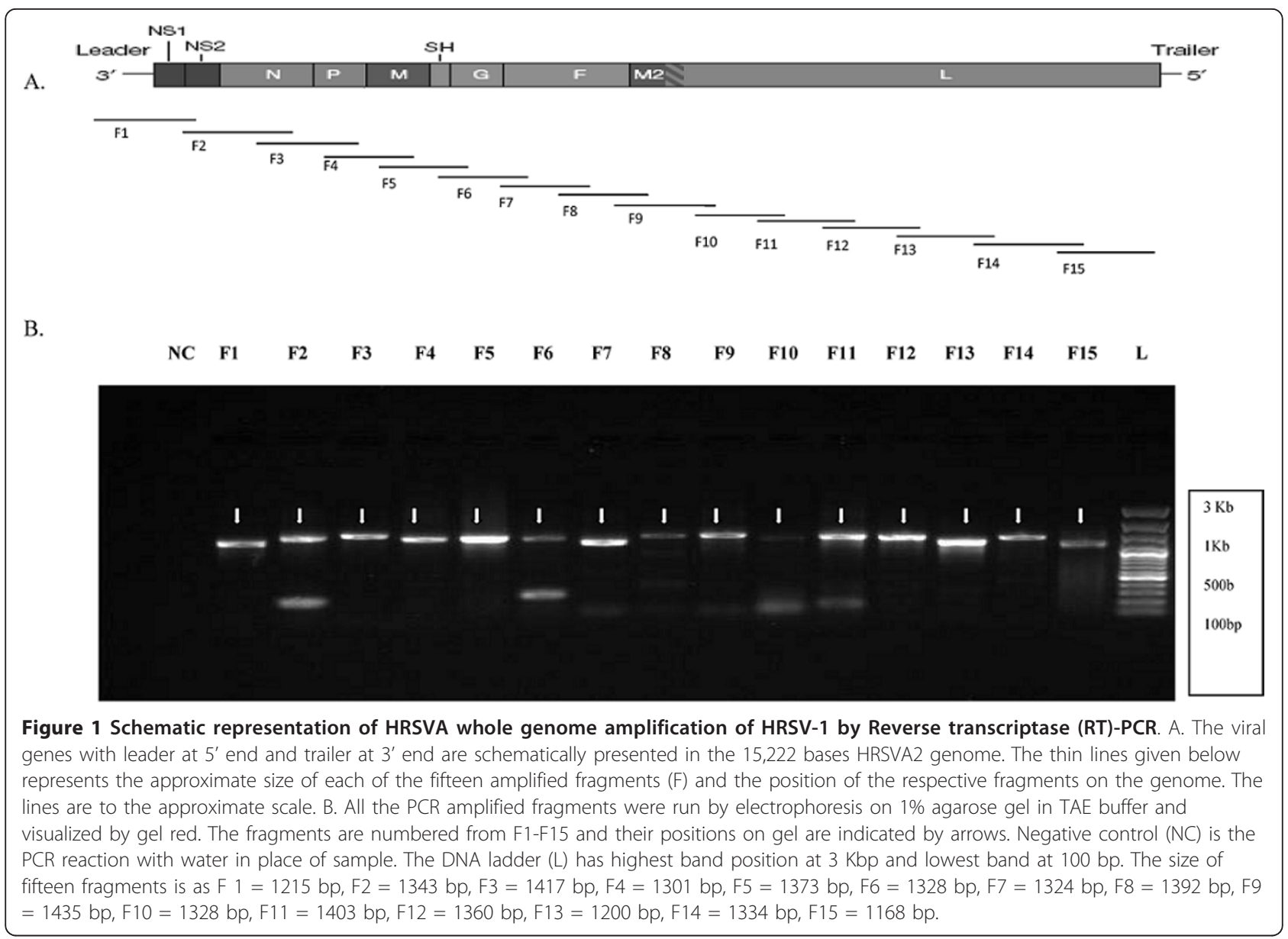

the 5'end of the vRNA, the full genome was amplified with help of fifteen primer sets. Each fragment was designed to have approximately 300 base pair overlap with adjacent fragments for better genome sequence coverage. Presence of M13 forward and reverse primer sequence in each PCR product helped the sequencing of all fifteen fragments in both the forward and reverse directions using these two primers only. Internal sequencing primers were used to sequence small sequencing gaps following sequencing of PCR fragments. The 3' end of genome could be completely sequenced using the reverse orientation primer RSVSTART and likewise 5' end was sequenced using a forward orientation primer RSVEND nucleotide position are with reference to A2 strain). RSVSTART binds to region in NS1 gene and sequence in reverse direction to cover till nucleotide 1 (start of genome), RSVEND primer binds in the $\mathrm{L}$ gene and covers the genome sequence till last nucleotide of genome. The methodology was initially evaluated using the well characterised HRSV A2 laboratory strain, and thereafter successfully applied to fourteen clinical strains.

\section{Primary clinical strains: Phylogenetic analysis and characterization of viral genome}

The length of the vRNA from the clinical strains ranged from 15,210 to 15222 nucleotides, with RSV-2 and RSV7 having the shortest and longest vRNA respectively (Table 1). The viral genome length of primary isolates is variable, similar to that reported in the prototype strains [25-30], with only one clinical strain (RSV-7) having the same size vRNA as the RSV A2 isolate. The variations were attributed mainly to deletions observed in the nontranslated regions, mainly between P-M and F-M2 (Figure 2).

We observed a generally high level of sequence conservation among the clinical strains examined in this study, and between the clinical strains and several RSV prototype strains. This suggested that selection pressure is towards conservation and/or that the genomic structure of HRSV may be relatively constrained. Phylogenetic analysis showed that the clinical strains represented a distinct lineage within HRSV A group, separate from the previously published cultured strains (Figure 3). The transition bias (R), which is an important 
Table 1 Comparison of the genome length (nucleotides) of the fourteen HRSVA clinical strains and transition bias (R) in clinical strains with reference to strain RSV-1 (Clinical reference strain)

\begin{tabular}{lccc}
\hline RSV A & $\begin{array}{c}\text { Genome } \\
\text { Length }\end{array}$ & $\begin{array}{c}\text { \% Nucleotide } \\
\text { Variability }\end{array}$ & $\begin{array}{c}\text { Transition Bias } \\
\text { (R) }\end{array}$ \\
\hline RSV -1 & 15,212 & - & Ref strain (RSV-1) $^{1}$ \\
\hline RSV-2 & 15,210 & 1.42 & 2.4 \\
\hline RSV-3 & 15,218 & 2.36 & 2.3 \\
\hline RSV-4 & 15,219 & 2.14 & 2.4 \\
\hline RSV-5 & 15,214 & 0.6 & 2.1 \\
\hline RSV-6 & 15,220 & 1.72 & 1.2 \\
\hline RSV-7 & 15,222 & 1.42 & 1.4 \\
\hline RSV-8 & 15,212 & 1.95 & 1.9 \\
\hline RSV-9 & 15,219 & 1.15 & 1.8 \\
\hline RSV-10 & 15,218 & 2.38 & 2.2 \\
\hline RSV-11 & 15,215 & 3.3 & 2.1 \\
\hline RSV-12 & 15,211 & 3.1 & 2.8 \\
\hline RSV-13 & 15,215 & 2.9 & 1.9 \\
\hline RSV-14 & 15,218 & 1.88 &
\end{tabular}

Lab adapted reference strain

\begin{tabular}{llll}
\hline \hline RSV A2 & 15222 & 3.30 & 2.9 \\
\hline RSS & 15191 & 2.67 & 2.4 \\
\hline Long & 15226 & 3.56 & 2.9 \\
\hline Line & 15191 & 3.58 & 2.9
\end{tabular}

$19^{*}$

${ }^{1}$ RSVA2 (lab adapted strain) is passaged several times in cell culture, thus may have numerous culture mediated mutations. Therefore, RSV-1, a strain obtained from a hospitalized RSVA patient is used as a reference strain for comparative analysis of RSVA strains from clinical source and published reference strains. * Nucleotide sequence for $5^{\prime}$ and $3^{\prime}$ ends of Line 19 is not available.

parameter of genetic sequence evolution, ranged between 1.2 and 2.8 for the clinical strains, also suggested comparatively lower evolution selection rate.

\section{Comparison of protein sequences encoded by the} clinical strains with prototype and published strains All genetic sequences from the clinical and prototype strains were translated in silico, and the resulting predicted protein sequences were compared.

\subsection{Integral membrane proteins}

The clinical strains showed a higher sequence variation in the $\mathrm{G}$ protein, which is consistent with a recent study suggesting selection pressure on $G$ protein based on Bayesian method implemented in the HyPhy program [35]. The clinical strains exhibited between 2.0 and 6.4\% variation in the amino acid sequence, and this variation was located mainly in the ectodomain region (Table 2, Additional file 2 Figure S1). Bio-informatics analysis has identified 29 amino acid positions in the G protein that are under positive selection pressure [35]. Comparison of the $\mathrm{G}$ protein sequence in the 14 clinical strains

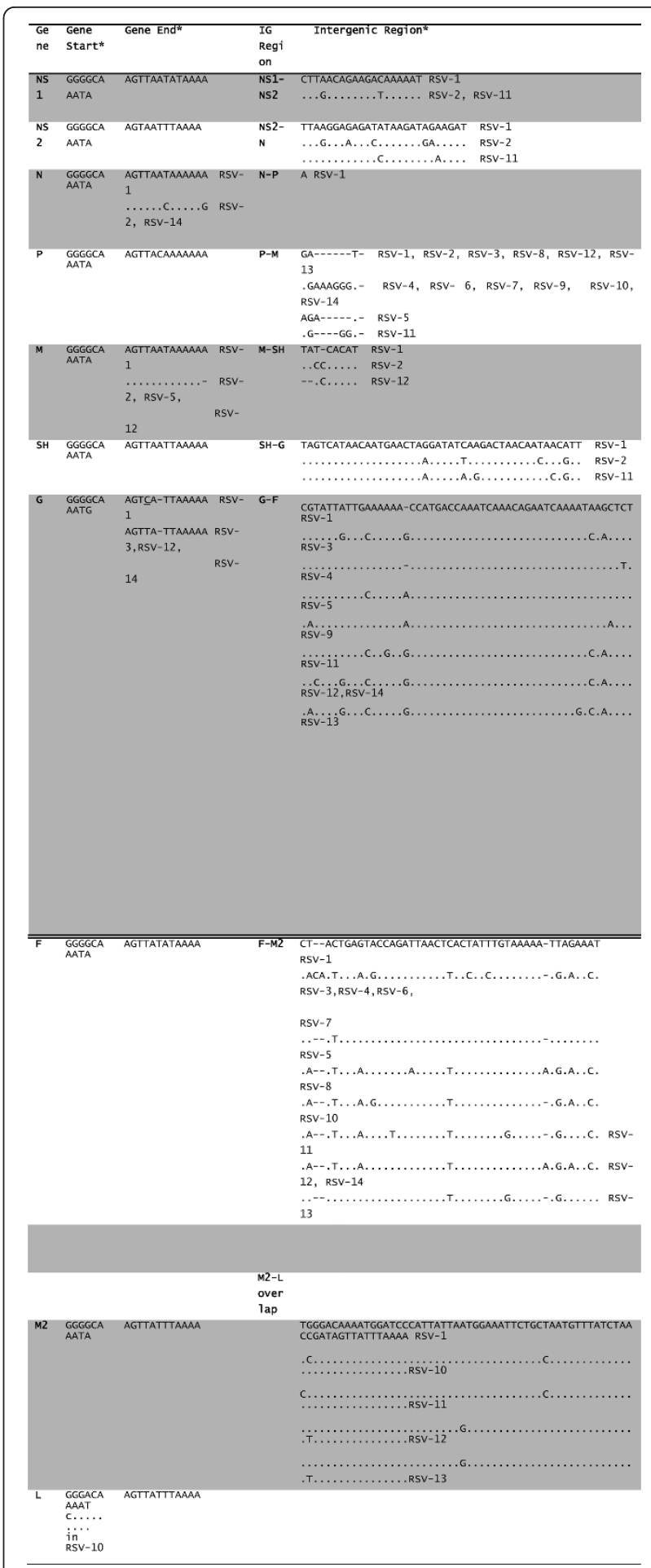

Figure 2 Nucleotide alignment and comparative analysis of the Gene Junction (Gene Start - Intergenic Region -Gene End) in strains from hospitalized patients. Genes identification is denoted before their corresponding GS and GE. Similarly corresponding intergenic region positions have also been denoted. An overlap instead of intergenic region is present between M2-L genes.

${ }^{*}$ Clinical strains having difference in the sequences are shown in the table. Thus rest of the sequences matched RSV-1. 


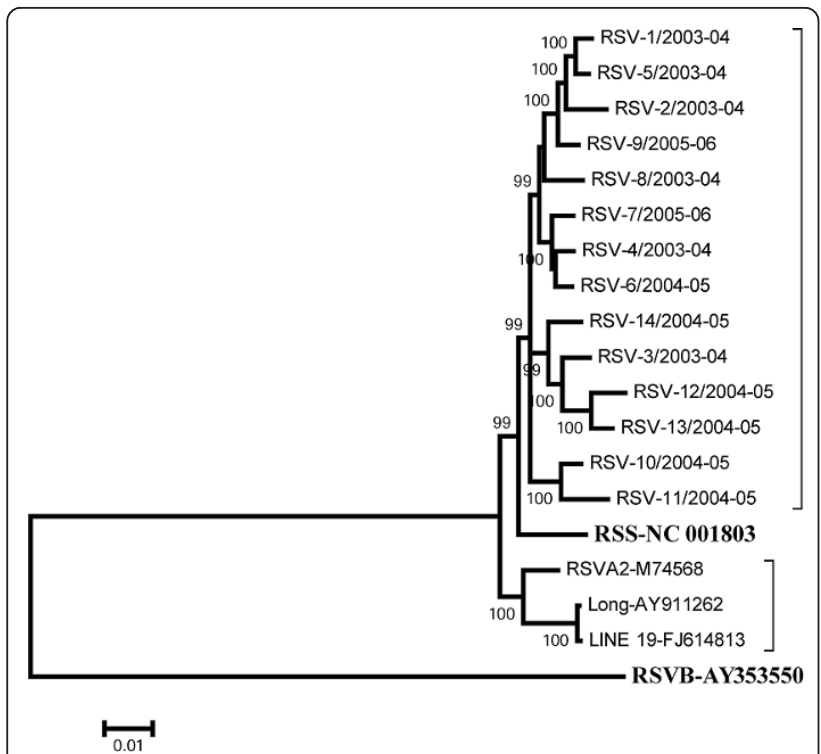

Figure 3 Phylogenetic relationship of 14 clinical strains of HRSVA from patients and 4 representative strains from the Genbank based on whole genome nucleotide sequence. Hospitalized patient strains have been indicated with prefix RSV. The reference strains are indicated by their Genbank accession number. The evolutionary history was inferred using the Neighbour-Joining method. The bootstrap values below $80 \%$ are not shown. The scale bar indicates $1 \%$ nucleotide sequence divergence. The HRSVB type (Accession number AY353550) has been used as the root.

Table 2 Amino acid variability (\%) identified in individual proteins of HRSVA: Comparison between hospitalized strains

\begin{tabular}{lccccccccccc}
\hline Strain & \multicolumn{10}{c}{ HRSVA Proteins (\% Amino acid variability) } \\
\hline & NS1 & NS2 & N & $\mathbf{P}$ & $\mathbf{M}$ & SH & G & F & L & M2-1 & M2-2 \\
\hline RSV-1 & & & & & & & & & & & \\
\hline RSV-2 & 0.7 & 2.4 & 0.25 & 0 & 0 & 0 & 5.4 & 1.21 & 0.27 & 0.25 & 0 \\
\hline RSV-3 & 0 & 0 & 0.25 & 0.4 & 0 & 0 & 5.4 & 1.74 & 1.06 & 0.33 & 0.88 \\
\hline RSV-4 & 0 & 0 & 0.5 & 0 & 0 & 0 & 2.34 & 1.91 & 1.01 & 0.33 & 0.44 \\
\hline RSV-5 & 0 & 0 & 0 & 0.4 & 0 & 0 & 3.3 & 1.91 & 0.18 & 0.25 & 0 \\
\hline RSV-6 & 0 & 0 & 0 & 0 & 0 & 0 & 2.7 & 1.91 & 0.69 & 0.33 & 0.55 \\
\hline RSV-7 & 0 & 0 & 0.5 & 0 & 0 & 0 & 2.7 & 1.74 & 0.2 & 0.33 & 0.44 \\
\hline RSV-8 & 0 & 0 & 0 & 0 & 0 & 0 & 2.01 & 1.39 & 0.46 & 0.25 & 0 \\
\hline RSV-9 & 0 & 0 & 0 & 0 & 0 & 0 & 2.34 & 1.21 & 0.54 & 0.38 & 0 \\
\hline RSV-10 & 0 & 0 & 0.25 & 0.4 & 0 & 0 & 2.01 & 1.56 & 1.08 & 0.38 & 0.33 \\
\hline RSV-11 & 0.7 & 2.4 & 0.5 & 0 & 0 & 0 & 6.4 & 2.09 & 1.15 & 0.38 & 0.44 \\
\hline RSV-12 & 0 & 0 & 0.5 & 0.4 & 0 & 0 & 5.4 & 1.91 & 1.38 & 0.55 & 0.55 \\
\hline RSV-13 & 0 & 0 & 0.5 & 0.4 & 0 & 0 & 6.4 & 2.61 & 1.47 & 0.60 & 0.55 \\
\hline RSV-14 & 0 & 0 & 0.5 & 0 & 0 & 0 & 5.7 & 2.61 & 0.55 & 0.55 & 0.44 \\
\hline
\end{tabular}

HRSVA2 (lab adapted strain) is passaged several times in cell culture, thus may have numerous culture mediated mutations. Therefore, RSV-1, a strain obtained from a hospitalized RSVA patient is used as a reference strain for comparative analysis of the proteins of RSVA strains from clinical source. indicated the presence of 14 of these sites, at L-215-P, P-222-S, V-225-A, P-226-F, T-227-S, P-256-L, F-265-L, S-269-T, T-274-P, I-279-V, L-286-P, P-289-S, P-290-L, S-293-P. Amino acid variation observed at five of these sites (position 274, 279, 286, 290 and 293) differed in the most of the clinical strains compared to the four cultured reference strains (Table 3). Antigenic epitopes have been identified in the G protein [36-38] and we noted a degree of amino acid sequence variation at these sites. The following amino acid changes in the G protein of the clinical strains; T-244-R (in RSV-2, RSV13, ) and F-265-L (in RSV-2, RSV-3, RSV-5, RSV-9, RSV-11, RSV-13, RSV-14) may be associated with loss of these antigenic epitopes.

The G protein plays an important role in attachment of the virus to the host cell [11], along with several cellular factors which have been proposed to mediate HRSV attachment $[39,40]$. At least two interactions between the $G$ protein and cellular factors have been described, and the properties of the $G$ proteins that mediate these interactions are conserved in the clinical strains. The G protein, amino acid motif $182-186$, which is proposed to have structural similarity to $\mathrm{CX} 3 \mathrm{C}$ chemokine fractalkine [40], is completely conserved in all the primary strains. Similarly the heparin binding site and the cysteine rich central domain in the G protein [41] were completely conserved in all the clinical strains.

The $\mathrm{F}$ protein exhibited a relatively higher sequence conservation [Additional file 3 Figure S2], which presumably reflects its importance in mediating virus entry, and sequence variation was highest in the signal sequence, transmembrane and cytoplasmic domains. The essential features of the $F$ protein were largely conserved in the clinical strains, including the two furin cleavage sites and the potential $\mathrm{N}$-linked glycosylation sites. These furin cleavage sites have been proposed to generate a short 27 amino acid glycopeptide in virusinfected cells [42], and among the clinical strains we observed a relatively high degree of sequence variation in the putative glycopeptides. The biological significance of this in humans is currently unclear, although the corresponding glycopeptide in the closely related bovine RSV exhibits tachykinin activity [43]. Several neutralizing antibody epitope sites have been identified, including 7C2 (aa221-236), 47F (aa262-268) and RS-348 (aa205225) [44] and these are completely conserved in all clinical strains. Of sequences related to cytotoxic T-lymphocyte (CTL) epitopes, a single substitution was observed at F-547-L, which has been reported in the HLA Cw*12 CTL epitope [45].

The recently characterized cell cultured Line 19 strain is suggest to be highly mucogenic [28], and is found to have six unique amino acid differences in the $\mathrm{F}$ protein 
Table 3 Comparative analysis of G protein amino acid positions under positive selection pressure in primary strains compared with prototype strains

\begin{tabular}{|c|c|c|c|c|c|}
\hline Amino acid & Pro & rains & & & Primary Clinical \\
\hline $215 \mathrm{~L}$ & & RSS & LONG & $\mathrm{L}-19$ & RSV-1, RSV-2 \\
\hline 215P & $\mathrm{A} 2$ & & & & RSV-3 to RSV-14 \\
\hline $222 \mathrm{P}$ & & RSS & LONG & $\mathrm{L}-19$ & RSV-1, RSV-2, RSV-11 \\
\hline $222 S$ & A2 & & & & RSV-3 to RSV-10, RSV- 12 to RSV- 14 \\
\hline $225 \mathrm{~V}$ & $\mathrm{~A} 2$ & RSS & LONG & $\mathrm{L}-19$ & RSV-1, RSV-3 to RSV-10 \\
\hline $225 \mathrm{~A}$ & & & & & RSV-2, RSV-11 \\
\hline $226 \mathrm{P}$ & $\mathrm{A} 2$ & RSS & LONG & $\mathrm{L}-19$ & RSV-1 to RSV-10,RSV-12 to RSV-14 \\
\hline $226 \mathrm{~F}$ & & & & & RSV-11 \\
\hline $227 \mathrm{~T}$ & $\mathrm{~A} 2$ & RSS & LONG & $\mathrm{L}-19$ & RSV-1, RSV-3 to RSV-14 \\
\hline 2275 & & & & & RSV-2 \\
\hline $256 \mathrm{P}$ & $\mathrm{A} 2$ & RSS & LONG & $\mathrm{L}-19$ & RSV-1, RSV-3, RSV-4, RSV-6 to RSV-10, RSV-12, RSV-14 \\
\hline $256 \mathrm{~L}$ & & & & & RSV-2, RSV-5, RSV-11 \\
\hline $256 \mathrm{Q}$ & & & & & RSV-13 \\
\hline $265 \mathrm{~F}$ & $\mathrm{~A} 2$ & & LONG & $L-19$ & RSV-1, RSV-4, RSV-6 to RSV-8, RSV-10, RSV-12 \\
\hline $265 \mathrm{~L}$ & & RSS & & & RSV-2, RSV-3, RSV-5, RSV-9, RSV-11, RSV-13, RSV-14 \\
\hline 2695 & $\mathrm{~A} 2$ & RSS & LONG & $\mathrm{L}-19$ & RSV-1, RSV-2, RSV-4 to RSV-12 \\
\hline 269T & & & & & RSV-3, RSV-13, RSV-14 \\
\hline $274 T$ & & & & & RSV-1, RSV-2, RSV-4 to RSV-6, RSV-8 to RSV-10 \\
\hline 274P & $\mathrm{A} 2$ & RSS & & & RSV-3, RSV-11 to RSV-14 \\
\hline $274 \mathrm{~L}$ & & & LONG & $\mathrm{L}-19$ & \\
\hline 2745 & & & & & RSV-7 \\
\hline 2791 & & & & & RSV-1 to RSV-10 \\
\hline $279 \mathrm{~V}$ & $\mathrm{~A} 2$ & RSS & LONG & $L-19$ & RSV-11 to RSV-14 \\
\hline $286 \mathrm{~L}$ & & RSS & & & RSV-1 to RSV-10 \\
\hline $286 \mathrm{P}$ & $\mathrm{A} 2$ & & LONG & $\mathrm{L}-19$ & RSV-11 \\
\hline $289 \mathrm{P}$ & $\mathrm{A} 2$ & RSS & LONG & $\mathrm{L}-19$ & RSV-1, RSV-2 \\
\hline 2895 & & & & & RSV-3, RSV-12 to RSV-14 \\
\hline $290 P$ & & RSS & & & RSV-1, RSV-2, RSV-4 to RSV-11 \\
\hline $290 \mathrm{~L}$ & & & & & RSV-3, RSV-12 to RSV-14 \\
\hline $290 S$ & $\mathrm{~A} 2$ & & LONG & $\mathrm{L}-19$ & \\
\hline 2935 & & RSS & & & RSV-1 to RSV-14(All clinical strains) \\
\hline $293 P$ & A2 & & LONG & L-19 & \\
\hline
\end{tabular}

when compared with the F protein sequence in HRSV A2 and long type [28]. However, neither of these differences were observed in the $F$ protein sequence of the clinical strains, thus the clinical relevance of these $\mathrm{F}$ protein sites is uncertain. Palivizumab (PZ) is the humanized murine monoclonal $\mathrm{Ab}(\mathrm{mAb})$ widely used for prophylaxis against RSV infection in high risk infants and children that binds to the $\mathrm{F}$ protein at aa422-438 [46]. A panel of resistant mutations in the $F$ gene in the binding site, F212, MP4, MS312, MS412 MS512 have been identified against PZ in vitro and in vivo studies [47-49]. Also, a number of mutations have been identified in the coding regions for the binding sites on the $\mathrm{F}$ protein for MAb19, RHZ19 and ch101F, other potent
mAbs, with clinical potential $[49,50]$. There were no sequence variation at these sites in the clinical strains examined in our study.

The SH membrane protein was completely conserved in all the clinical strains. While the sequence conservation of the $\mathrm{SH}$ has been previously reported, suggesting that it may be clinically relevant [51], and the SH protein is dispensable for virus replication in tissue culture [52]. Our own studies employing siRNA to inhibit $\mathrm{SH}$ gene expression ( $\mathrm{Ng}$ and Sugrue, unpublished observations) support this observation.

\subsection{Polymerase associated proteins}

The L, P, N and M2-1 genes which encode the polymerase and associated proteins also showed very low 
sequence variability. Alignment of deduced L protein sequence of our strains with other published sequences on NCBI BLAST revealed that presence of asparagine or tyrosine at position 148 and glycine at 174 are exclusive to our clinical strains The variation at aa148 led to replacement of negatively charged amino acid with that having neutral side chain and at aa174, it changed the polar negatively charged amino acid with non polar neutral. These substitutions are located before domain I of $\mathrm{L}$ protein, proposed as nucleotide binding domain $[53,54]$. There were few amino acid variations in the $\mathrm{N}$, $\mathrm{L}$ and $\mathrm{P}$ proteins. Two substitutions identified in the $\mathrm{N}$ protein of clinical strains, L-64-V was identified in seven (RSV-1, RSV-2 RSV-3 RSV-5 RSV-6 RSV-7 RSV-9) and $\mathrm{R}-84-\mathrm{K}$ in five (RSV-8, RSV-11 to RSV-14). Although the overall sequence of the $\mathrm{L}$ protein was comparatively conserved among the clinical strains, we observed that M-59-I, L-81-I, I-2016-V differed from that in the A2, Long and Line 19. Two exclusive differences found predominantly among our clinical strains were at D-148-N/ $\mathrm{Y}$ and V/D-174-G in strains RSV-1, RSV-2, RSV-4 to RSV-10, RSV-14 and strains RSV-1 to RSV-9, RSV-14 respectively. (Table 4; Additional file 4 Figure S3). With the exception of a single amino acid difference at A-73$\mathrm{V} / \mathrm{T}$ in RSV-3, RSV-10, RSV-11, RSV-12 RSV-13, the P protein remained conserved in all the clinical strains. The $M$ protein showed $100 \%$ conservation in all the clinical strains examined (Table 2).

The transcription elongation factor M2-1 is highly conserved among the clinical strains, along with the Cys
(3)-His(1) motif that is important for its functionality $[55,56]$. While amino acid variability was extremely low for the M2-1 protein (between 0.25-0.6\%) among clinical strains, exclusive substitutions I-87-L in RSV-12 to RSV14 and $\mathrm{N}-117-\mathrm{T} / \mathrm{S}$ in RSV-8, RSV-10, RSV-11-14 were observed (Table 4; Additional file 5 Figure S4). M2-2 is proposed to shift the balance from vRNA transcription to vRNA replication $[57,58]$. We noted a degree of M22 protein sequence variation between the clinical strains and those reported for several HRSV prototype viruses. In addition, the absence of the first start codon in $71 \%$ of the clinical strains suggested the expression of shorter M2-2 protein.

Interestingly, the M2-2 protein sequence showed a relatively large number of sequence variations when compared with prototype cultured viruses. We observed a $11.11 \%$ difference in the M2-2 protein sequence of all the clinical strains as compared to the reference strain (Table 4). The substitution M-1-T effectively removed the first start codon, and thus M2-2 is predicted to be 88 aa rather than 90 aa in length in 10 clinical strains due to availability of second start codon for the protein (Additional file 6 Figure S5). As the M2-2 protein plays a role in vRNA replication, the functional significance of the sequence variations in the M2-2 protein in RSV vRNA replication will require further examination.

In four clinical strains nucleotide substitutions have been observed at five different positions in M2-L gene overlap sequence, while changes at only two of positions were reported earlier by Moudy et al [59]. Moreover,

Table 4 Nucleotide changes leading to amino acid substitutions in F, L, M2-1 and M2-2 proteins exclusively in primary clinical HRSVA strains as compared to reference strains

\begin{tabular}{|c|c|c|c|}
\hline Protein & Nucleotide change in Primary strains & Amino acid substitution - Position & Primary strains having substitution \\
\hline $\mathrm{F}$ & $\mathrm{CTC} / \mathrm{CTT} \rightarrow \mathrm{TT}$ & L-15-F & RSV-1, RSV-2,RSV-7 to RSV-10 \\
\hline \multirow[t]{3}{*}{ L } & $\mathrm{GAC} \rightarrow \mathrm{AAC} / \mathrm{TAC}$ & $\mathrm{D}-148-\mathrm{N} / \mathrm{Y}$ & RSV-1, RSV-2, RSV-4 to \\
\hline & $\mathrm{GTC} / \mathrm{GAC} \rightarrow \mathrm{GGC}$ & V/D-174-G & RSV-10, RSV-14 \\
\hline & & & RSV-1 to RSV-9, RSV-14 \\
\hline \multirow[t]{2}{*}{ M2-1 } & ATA $\rightarrow$ CTA & I-87-L & RSV-12 to RSV-14 \\
\hline & $\mathrm{AAA} \rightarrow \mathrm{AGT}$ & N-117-S & RSV-8, RSV-10, RSV-11 \\
\hline \multirow[t]{12}{*}{$M 2-2^{*}$} & $\mathrm{ATG} \rightarrow \mathrm{ACG}$ & M-1-T & RSV-1, RSV-2, RSV-5, RSV-8 to RSV-14 \\
\hline & $\mathrm{ACT} \rightarrow \mathrm{AAT}$ & T-18-N & RSV-1, RSV-2, RSV-5, RSV-7 to RSV-14 \\
\hline & $\mathrm{AGA} \rightarrow \mathrm{AAT} / \mathrm{AGT}$ & $\mathrm{R}-25-\mathrm{N} / \mathrm{S}$ & RSV-1, RSV-2, RSV-5, RSV-8 to RSV-14 \\
\hline & $\mathrm{TTC} \rightarrow \mathrm{ATC}$ & F-39-I & RSV-12 to RSV-14 \\
\hline & $\mathrm{CCA} \rightarrow \mathrm{CAA}$ & P-44-Q & RSV-1, RSV-2, RSV-4, RSV-5, RSV-8 to RSV- 14 \\
\hline & ATG $\rightarrow$ ATA/ACG & $M-48-1 / T$ & RSV-1, RSV-2, RSV-5, RSV-7 to RSV-14 \\
\hline & $\mathrm{CCA} \rightarrow \mathrm{CAG}$ & $P-51-Q$ & RSV-12 to RSV-14 \\
\hline & $\mathrm{ACA} \rightarrow \mathrm{CCA}$ & T-54-P & RSV-1, RSV-2, RSV-4 to RSV-14 \\
\hline & $\mathrm{ACA} \rightarrow \mathrm{GCA}$ & T-68-A & RSV-1 to RSV-14 \\
\hline & $\mathrm{ATT} \rightarrow \mathrm{ACT}$ & I-69-T & RSV-3 to RSV-10, RSV-14 \\
\hline & $\mathrm{ATT} \rightarrow \mathrm{ACT}$ & I-79-T & RSV-1 to RSV-6, RSV-8, RSV-9, RSV- 12 to RSV- 14 \\
\hline & $\mathrm{GAG} \rightarrow \mathrm{GAT}$ & $E-80-D$ & RSV-1 to RSV-14 \\
\hline
\end{tabular}

*In the deduced M2-2 protein sequence, the RSS strain had difference at only I-48-T. 
nucleotide change A-26-G observed in RSV-12 and RSV13 led to changes of amino acid N-6-S in L protein.

The $\mathrm{M}$ genes nucleotide sequence was completely conserved in the clinical strains, which is consistent with the importance of the $\mathrm{M}$ protein, both as a major structural protein, and a regulator of virus polymerase activity [9]. 3.3 Non-structural proteins:

Both the NS1 and NS2 proteins were highly conserved, with only one amino acid substitution L-105-I in the NS1 protein of RSV-2, RSV-11, and three subsitutions in the NS2 protein (D-7-G, N-8-T, K-38-R) present in the same clinical strains (RSV-2, RSV-11). The NS1 and NS2 proteins showed little sequence variation, underlining the essential roles these proteins play in evading the host innate immune response [60]. Recently siRNA targeting the NS1 protein has been proposed as an effective therapeutic strategy [61], and the conserved nature of the NS1 nucleotide sequence suggests that these siRNA molecules will also be effective against a range of RSV strains in the severe clinical scenario.

\section{Sequence analysis of the non-transcribed gene junction and extragenic regions}

The non translated regions of the vRNA are likely to play important roles in the regulation of virus genes expression [62]. The nucleotide sequence of the leader region was highly conserved, with only a single A to G nucleotide substitution at nt29 in the strains RSV-2, RSV-11. All the clinical strains had Cytosine at nt4 in the leader sequence, which is important in the context of virus replication [63]. Although we noted an overall conservation in the trailer sequence, some regions of increased sequence variation were apparent. Moreover, the length of trailer region varied between 153-162 nt among the clinical strains. The sequence for the proposed polymerase binding site (nt 1-11 of leader) [64] is completely conserved among all clinical strains. While GS sequences were well conserved among all clinical strains, the GE sequences showed a higher degree of variation. The GS sequences were conserved in the first 9 genes, and only the GS sequence preceding the L gene showed some variation. A subsitution in the GS sequeunce (to $\mathrm{U}$ or $\mathrm{A}$ ) at nt1 was reported to significantly reduce transcription levels [65], but the functional significance of $\mathrm{G}$ to $\mathrm{C}$ found in the GS region of $\mathrm{L}$ polymerase gene is uncertain (Figure 2). The GE was conserved for 8 genes. The GE sequence of the $\mathrm{N}$ gene had a change at nt 7 and nt 13 in RSV-2, RSV-14, the M gene had one nucleotide shorter in RSV-2, RSV-5, and RSV-12, while in $78 \%$ of clinical strains there was a substitution at nt4 in GE sequence of the G. The changes in $\mathrm{GE}$ sequence of the $\mathrm{G}$ gene such as substitution at nt 4 and shorter central region have been associated with altered the transcription termination efficiency $[66,67]$.
By comparison with the GS and GE regions, the IG regions showed a higher degree of sequence variation. The IG sequence of the P-M gene junction varied in length between 3-9 nts, while that of the G-F and the FM2 gene junctions also exhibited greater sequence variation amongst clinical strains. Although the significance of this sequence variation among the clinical strains is uncertain, in vitro studies have demonstrated that the IG region can play important role in regulating virus gene transcription [68]. It is therefore possible that these sequence variations may lead to altered viral gene expression characteristics among the different clinical strains.

\section{Biological properties of the clinical isolates}

HRSV remains largely cell-associated, and infection occurs by direct cell to cell contact [34]. In cells infected with the prototype HRSV isolate A2, two distinct virus structures are formed during the virus replication cycle; the virus filaments (VF) and inclusion bodies (IB). The VF are membrane-bound structures that are 150-200 $\mathrm{nm}$ thick and can be up to $4 \mu \mathrm{m}$ in length. They form at the sites of virus assembly and are the mature progeny viruses [34]. The inclusion bodies form in the cytoplasm of infected cells and can be several $\mu \mathrm{m}$ in diameter, consisting of RNP complexes, together with several essential cellular factors. These structures have been extensively examined using laboratory HRSV isolates (e.g. HRSV A2), and we examined HEp2 cells infected with the RSV clinical strains. Most of the RSV strains described in this study could not be recovered using tissue culture, which may be due to differences in the level of infectious virus particles in the starting clinical material. This is difficult to estimate using molecular techniques (e.g. qPCR), which only assesses the levels of vRNA copies, and does not distinguish between infectious and non-infectious virions. However, we were able to recover three clinical strains; RSV-4, RSV-8 and RSV13 from infected HEp2 cells. This was confirmed by labeling of cells infected with the clinical strains using the anti-RSV and anti-mouse IgG conjugated to FITC as described previously [34], which allows visualisation of both the virus filaments and inclusion bodies. In each case infection with the clinical isolates could only be detected between 2 and 4 days post infection, and the stained cells appeared either singly or in small clusters (Figure 4A; white arrowhead). This was considerably slower compared to HRSV A2 (Figure 4A), where large numbers of infected cells and extensive syncytia could be detected by day 2 (Figure 4A; highlighted by white box). This is consistent with recent observations suggesting slower replication kinetics of clinical HRSV strains compared to laboratory prototype isolates [69] Examination of the stained cells revealed the presence 

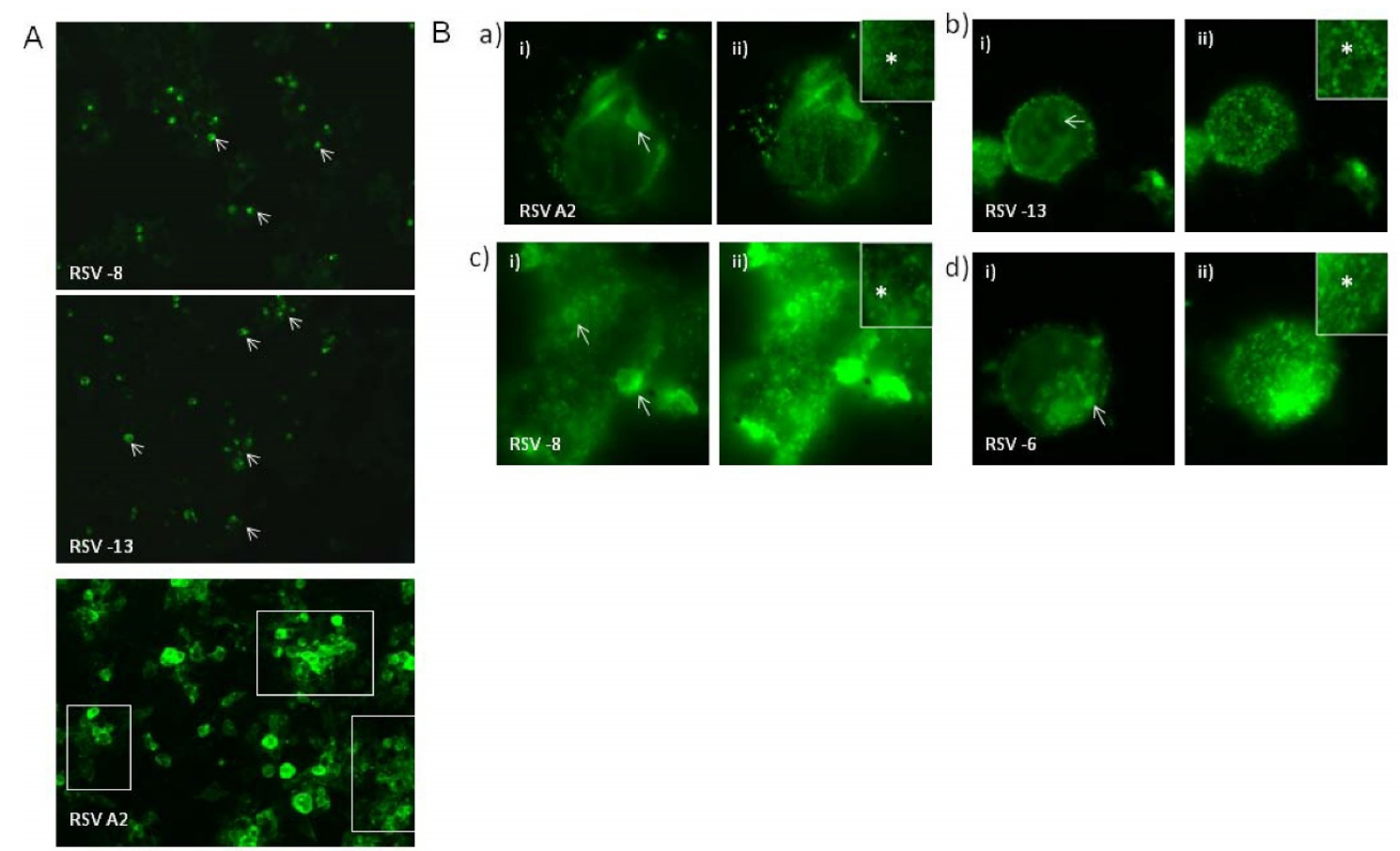

Figure 4 Immunofluorescence examination of cells infected with the HRSV clinical strains. (A) Differential infection levels were observed with clinical isolates as compared to lab strain RSVA2. More HEp 2 cells were seen infected with RSVA2, when compared with clinical isolate RSV-8 and RSV-13 between 2 and 4 days post infection. (B). Clinical isolates (b) RSV-13, (c) RSV-8 and (d) RSV-6 also produced similar structures like (a) RSVA2. HEp2 cells were infected with RSVA2 and clincial isolates were stained with anti-RSV antibodies and visualized by

immunofluorescence using secondary antibodies conjugated to FITC. Examination of the stained cells at a focal plane showing mainly the i) interior and ii) surface of infected cells are shown in each case. The presence of large cytoplasmic inclusion bodies highlighted by white arrow and presence of structures that resembled the VF are highlighted by star.

of large cytoplasmic inclusion bodies (Figure 4B; highlighted by white arrow), as well as structures that resembled the VF (Figure 4B; highlighted by *). This suggests that the clinical strains produce structures similar to that observed in HRSV A2 infected cells. Several cellular factors have been identified within inclusion bodies and virus filaments using RSV prototype strains, and these cellular factors have been implicated in aspects of the HRSV replication cycle e.g. virus particle assembly [70]. The formation of similar structures in cells infected with the clinical strains suggests a similar mechanism in both HRSV A2 and the clinical strains during virus replication, and supports a clinical role these structures during HRSV infection.

\section{Conclusions}

We report the complete genetic characterisation of fourteen clinical HRSV strains that were sequenced directly from clinical material obtained from severely ill children. In general a high degree of nucleotide sequence conservation was observed, both between the different clinical strains, and between the clinical and prototype strains.
This was consistent with a low evolution rate for HRSV. Analysis of the protein coding regions of the HRSV genomes indicated that the $G$ protein showed the greatest sequence variation between the clinical stains. Although the $\mathrm{F}$ protein showed a small degree of sequence variation, the essential features of the F protein (e.g. protease cleavage site) were conserved, together with several important antigenic epitopes. The protein coding region of the $\mathrm{M}$ and $\mathrm{SH}$ genes were entirely conserved, while all other virus genes showed small degrees of sequence variation. In some clinical strains the M2-2 gene showed an alternative translational start site, which would be expected to give rise to a smaller M2-2 protein lacking the first two amino acids. Analysis of the non-translated regions between the clinical strains indicated that leader and trailer regions region were highly conserved, although a small degree of sequence variation at specific regions in the trailer region was noted. The gene start regions showed a high degree of sequence conservation, while the gene end sequences were conserved for 8 genes. In contrast the intergenic regions showed a significantly higher degree of sequence variation between 
the different clinical strains. In tissue culture cells the clinical strains grew much slower than the prototype HRSV A2 stain. However, the formation of inclusion bodies and virus filaments were observed in HEp 2 cells infected with either the prototype A2 stain or clinical strains, suggesting a clinical relevance for these virusinduced structures.

\section{Additional material}

Additional file 1: Table S1: Oligonucleotide primers used for reverse transcriptase-polymerase chain reaction (RT-PCR) amplification of HRSVA clinical strains and HRSVA2 strains

Additional file 2: Figure S1: Amino acid sequence alignment and comparative analysis of glycoprotein between primary HRSVA strains and prototype cultured strains. The domain name with amino acid position is indicated above the sequence alignment

Additional file 3: Figure S2: Amino acid sequence alignment and comparative analysis of fusion protein between primary HRSVA strains and prototype cultured strains. The domain name with amino acid position is indicated above the sequence alignment. All the glycosylation sites are given in bold and underlined.

Additional file 4: Figure S3: Amino acid alignment and comparative analysis of L-protein between primary HRSVA strains and prototype cultured strains.

Additional file 5: Figure S4: Amino acid alignment and comparative analysis of M2-1 protein between primary HRSVA strains and prototype cultured strains.

Additional file 6: Figure S5: Amino acid alignment and comparative analysis of M2-2 protein between primary HRSVA strains and prototype cultured strains.

\section{Abbreviations}

HRSV: Human respiratory syncytial virus; NT: Nucleotides; VF: Virus filaments; IB: Inclusion bodies; LRTI: Lower Respiratory Tract infections; BPD: Bronchopulmonary dysplasia; CLD: Chronic Lung Disease; CHD: Coronary Heart Disease; PDA: Patent Ductus Arteriosus; CPAP: Continuous Positive Airway Pressure; DTT: Dithiothritol; RT: Reverse transcriptase; FITC: fluorescent isothiocyanate; GS: Gene start; GE: Gene end; IG: Intergenic region; PZ: Palivizumab; mAb: monoclonal antibodies; ALRI: acute lower respiratory infections; PBS: Phosphate Buffered Saline.

\section{Acknowledgements}

This publication was supported by Singapore-MIT Alliance for Research and Technology (SMART) and NIH/NCRR Colorado CTSI (Grant Number UL1 RR025780). Laxmi Ravi lyer is a recipient of NTU PhD scholarship (MOE). The contents are the authors' sole responsibility and do not necessarily represent official NIH views. We acknowledge the Jessica Cowden, Elizabeth Crawford and KC Clavenger for assistance with obtaining specimens from patients, Pauline and Liang for technical support and the parents and infants who were in the study.

\section{Author details}

${ }^{1}$ Singapore-MIT Alliance for Research and Technology, Centre for Life Sciences, \#05-06M, 28 Medical Drive, 117456, Singapore. ${ }^{2}$ Division of Molecular and Cell biology, School of Biological Sciences, Nanyang Technological University, 60 Nanyang Drive, 639798, Singapore. ${ }^{3}$ Genome Institute of Singapore, \#02-01, Genome Building, 60 Biopolis Street, 138672, Singapore. ${ }^{4}$ University of Colorado, Denver and The Division of Infectious Diseases, The Children's Hospital, 13123 East 16th Avenue, Aurora, CO 80045, USA.

\section{Authors' contributions}

RK performed the sequencing analysis and assisted in drafting the manuscript, LIR performed virus tissue culture experiments and assisted in formatting of the manuscript. MLH, EAFS and RJS conceived of the study and participated in its design and coordination. All authors have read and approved the final manuscript.

\section{Competing interests}

The authors declare that they have no competing interests.

Received: 22 April 2011 Accepted: 28 July 2011 Published: 28 July 2011

\section{References}

1. WHO Initiative for Vaccine Research: Acute Respiratory Infections (Update September 2009).[http://www.who.int/vaccine_research/diseases/ari/en/ index.html], Accessed 13 August 2010.

2. Nair H, Nokes DJ, Gessner BD, Dherani M, Madhi SA, Singleton RJ, O'Brien KL, Roca A, Wright PF, Bruce N, Chandran A, Theodoratou E, Sutanto A, Sedyaningsih ER, Ngama M, Munywoki PK, Simões EAF, Martin IR, Weber W, Campbell H: Global burden of acute lower respiratory infections due to respiratory syncytial virus in young children: systematic review and meta-analysis. Lancet 2010, 375(9725):1545-1555.

3. Collins PL, Hill MG, Cristina J, Grosfeld H: Transcription elongation factor of respiratory syncytial virus, a nonsegmented negative-strand RNA virus. Proc Natl Acad Sci USA 1996, 93:81-85.

4. Grosfeld $H$, Hill MG, Collins PL: RNA replication by respiratory syncytial virus (RSV) is directed by the N, P, and L proteins; transcription also occurs under these conditions but requires RSV superinfection for efficient synthesis of full-length mRNA. J Virol 1995, 69:5677-5686.

5. $Y u$ Q, Hardy RW, Wertz GW: Functional cDNA clones of the human respiratory syncytial (RS) virus $N, P$, and $L$ proteins support replication of RS virus genomic RNA analogs and define minimal trans-acting requirements for RNA replication. J Virol 1995, 69:2412-2419.

6. Jin H, Cheng $X$, Zhou HZ, Li S, Seddiqui A: Respiratory syncytial virus that lacks open reading frame 2 of the M2 gene (M2-2) has altered growth characteristics and is attenuated in rodents. J Virol 2000, 74(1):74-82

7. Bermingham A, Collins PL: The M2-2 protein of human respiratory syncytial virus is a regulatory factor involved in the balance between RNA replication and transcription. Proc Natl Acad Sci USA 1999, 96:11259-11264.

8. Fearns $\mathrm{R}$, Collins PL: Role of the M2-1 transcription antitermination protein of respiratory syncytial virus in sequential transcription. J Virol 1999, 73:5852-5864.

9. Ghildyal R, Mills J, Murray M, Vardaxis N, Meanger J: Respiratory syncytial virus matrix protein associates with nucleocapsids in infected cells. J Gen Virol 2002, 83:753-757.

10. Hardy RW, Wertz GW: The product of the respiratory syncytial virus M2 gene ORF1 enhances read-through of intergenic junctions during viral transcription. J Virol 1998, 72:520-526.

11. Levine SR, Klaiber-Franco, Paradiso PR: Demonstration that glycoprotein G is the attachment protein of respiratory syncytial virus. J Gen Virol 1987, 68:2521-2524.

12. Scheid A, Choppin PW: Two disulfide-linked polypeptide chains constitute the active F protein of paramyxoviruses. Virology 1977 , 80:54-66.

13. Schlender J, Bossert B, Buchholz U, Conzelmann KK: Bovine respiratory syncytial virus nonstructural proteins NS1 and NS2 cooperatively antagonize alpha/beta interferon-induced antiviral response. J Virol 2000, 74:8234-8242.

14. Mufson MA, Belshe RB, Orvell C, Norrby E: Two distinct subtypes of human respiratory syncytial virus. J Gen Virol 1985, 66:2111-2124

15. Cane PA, Matthews D, Pringle C: Identification of variable domains of the attachment $\mathrm{G}$ protein of subgroup A respiratory syncytial viruses. J Gen Virol 1991, 72:2091-2096.

16. Choi EH, Lee HJ: Genetic diversity and molecular epidemiology of the $G$ protein of subgroups $A$ and $B$ of respiratory syncytial viruses isolated over 9 consecutive epidemics in Korea. J Infect Dis 2000, 181:1547-1556.

17. Martinello RA, Chen M D, Weibel C, Kahn JS: Correlation between respiratory syncytial virus genotype and severity of illness. J Infect Dis 2002, 186:839-842. 
18. Rafiefard F, Johansson B, Tecle T, Orvell C: Molecular epidemiology of respiratory syncytial virus (RSV) of group A in Stockholm, Sweden, between 1965 and 2003. Virus Res 2004, 105:137-145.

19. da Silva LHA, Spilki FR, Riccetto AGL, de Almeida RS, Baracat ECE, Arns CW: Genetic Variability in the $G$ protein gene of human respiratory syncytial virus isolated from the Campinas metropolitan region, Brazil. J Med Virol 2008, 80:1653-1660.

20. Peret TC, Hall CB, Schnabel KC, Golub JA, Anderson JA: Circulation patterns of genetically distinct group $A$ and $B$ strains of human respiratory syncytial virus in a community. J Gen Virol 1998, 79:2221-2229.

21. Cane PA: Molecular epidemiology of respiratory syncytial virus. Rev Med Virol 2001, 11:103-116

22. Montieri S, Puzelli S, Ciccozzi M, Calzoletti L, Di Martino A, Milia MG, Rossi A, Piro F, Rezza G, Donatelli l: Amino acid changes in the attachment G glycoprotein of human respiratory syncytial viruses (Subgroup A) isolated in Italy over several epidemics (1997-2006). J Med Virol 2007, 79:1935-1942.

23. Gilca R, De Serres G, Tremblay M, Vachon ML, Leblanc E, Bergeron MG, Dery P, Boivin G: Distribution and Clinical Impact of Human Respiratory Syncytial Virus Genotypes in Hospitalized Children. J Infect Dis 2006, 193:54-58.

24. Kaplan NM, Dove W, Abd-Eldayem SA, Abu-Zeid AF, Shamoon HE, Hart CA: Molecular epidemiology and disease severity of respiratory syncytial virus in relation to other potential pathogens in children hospitalized with acute respiratory infection in Jordan. J Med Virol 2008, 80:168-174.

25. Collins PL, Olmsted RA, Spriggs MK, Johnson PR, Buckler-White AJ: Gene overlap and site-specific attenuation of transcription of the viral polymerase $\mathrm{L}$ gene of human respiratory syncytial virus. Proc Natl Acad Sci USA 1987, 84(15):5134-5138

26. Lo MS, Brazas RM, Holtzman MJ: Human respiratory syncytial virus strain ATCC VR-26, complete genome. 2009 [http://www.ncbi.nlm.nih.gov/ nuccore/60549163], Accessed 13 January 2009.

27. Mink MA, Stec DS, Collins PL: Nucleotide sequences of the $3^{\prime}$ leader and $5^{\prime}$ trailer regions of human respiratory syncytial virus genomic RNA Virology 1991, 185(2):615-624

28. Moore ML, Chi MH, Luongo C, Lukacs NW, Polosukhin W, Huckabee MM, Newcomb DC, Buchholz UJ, Crowe JE, Goleniewska K, Williams JV, Collins PL, Peebles S: A chimeric A2 strain of respiratory syncytial virus (RSV) with the fusion protein of RSV strain line 19 exhibits enhanced viral load, mucus, and airway dysfunction. J Virol 2009, 83(9):4185-4194.

29. Stec DS, Hill MG, Collins PL: Sequence analysis of the polymerase $L$ gene of human respiratory syncytial virus and predicted phylogeny of nonsegmented negative-strand viruses. Virology 1991, 183(1):273-287.

30. Tolley KP, Marriott AC, Simpson A, Plows D J, Mattews DA, Longhurst SJ, Evans JE, Johnson JL, Cane PA, Randolph VB, Easton AJ, Pringle CR: Identification of mutations contributing to the reduced virulence of a modified strain of respiratory syncytial virus. Vaccine 1996, 14:1637-1646.

31. Tamura $K$, Nei $M$, Kumar S: Prospects for inferring very large phylogenies by using the neighbor-joining method. Proc Natl Acad Sci USA 2004, 101:11030-11035.

32. Felsenstein J: Confidence limits on phylogenies: An approach using the bootstrap. Evolution 1985, 39:783-791

33. Tamura K, Dudley J, Nei M, Kumar S: MEGA4: Molecular evolutionary genetics analysis (MEGA) software version 4.0. Mol Biol Evol 2007, 24:596-1599.

34. Brown G, Aitken J, Rixon HW, Sugrue RJ: Caveolin-1 is incorporated into mature respiratory syncytial virus particles during virus assembly on the surface of virus-infected cells. J Gen Virol 2002, 83:611-621.

35. Botosso VF, Zanotto PM, Ueda M, Arruda E, Gilio AE, Vieira SE, Stewien KE, Peret TCT, Jamal LF, Pardini MIMC, Pinho JRR, Massad E, Sant'Anna OA, Holmes EC, Durigon EL, VGDN Consortium: Positive selection results in frequent reversible amino acid replacements in the $G$ protein gene of human respiratory syncytial virus. PLoS Pathogens 2009, , 1: e1000254 [http://www.plospathogens.org].

36. Garcia O, Martin M, Dopazo J, Arbiza J, Frabasile S, Russi J, Hortal M, PerezBrena P, Martinez I, Garcia-Barreno B, Melero JA: Evolutionary pattern of human respiratory syncytial virus subgroup $A$ : co circulating lineages and correlation of genetic and antigenic changes in the $\mathrm{G}$ glycoprotein. J Virol 1994, 68:5448-5459.

37. Martinez I, Dopazo J, Melero JA: Antigenic structure of the human respiratory syncytial virus $\mathrm{G}$ glycoprotein and relevance of hypermutation events for the generation of antigenic variants. $J$ Gen Virol 1997, 78:2419-2429.

38. Rueda P, Delgado T, Portela A, Melero JA, Garcia-Barreno B: Premature stop codons in the $G$ glycoprotein of human respiratory syncytial viruses resistant to neutralization by monoclonal antibodies. J Virol 1991, 65(6):3374-3378

39. Hallak LK, Spillmann D, Collins PL, Peeples ME: Glycosaminoglycan sulfation requirements for respiratory syncytial virus infection. J Virol 2000, 74(22):10508-10513.

40. Tripp RA, Jones LP, Haynes LM, Zheng HQ, Murphy PM, Anderson L: CX3C chemokine mimicry by respiratory syncytial virus $\mathrm{G}$ glycoprotein. Nat Immunol 2001, 2:732-738.

41. Steven A, Feldman R, Hendry M, Beeler JA: Identification of a linear heparin binding domain for human respiratory syncytial virus attachment glycoprotein G. J Virol 1999, 73(8):6610-6617.

42. Sugrue RJ, Brown C, Brown G, Aitken J, Rixon HW: Furin cleavage of the respiratory syncytial virus fusion protein is not a requirement for its transport to the surface of virus-infected cells. J Gen Virol 2001, 82:1375-1386.

43. Zimmer G, Rohn M, McGregor GP, Schemann M, Conzelmann KK, Herrler G: Virokinin, a bioactive peptide of the tachykinin family, is released from the fusion protein of bovine respiratory syncytial virus. J Biol Chem 2003, 278(47):46854-46861.

44. Agenbach $E$, Tiemessen $C T$, Venter M: Amino acid variation within the fusion protein of respiratory syncytial virus subtype $A$ and $B$ strains during annual epidemics in South Africa. Virus Genes 2005, 30(2):267-278.

45. Brandenburg AH, De-Waal L, Timmerman HH, Hoogerhout P, De-Swart RL, Osterhaus AD: HLA class I-restricted cytotoxic T-cell epitopes of the respiratory syncytial virus fusion protein. J Virol 2000, 74:10240-10244.

46. IMPACT-RSV Study Group: Palivizumab, a humanized respiratory syncytial virus monoclonal antibody, reduces hospitalization from respiratory syncytial virus infection in high-risk infants. Pediatrics 1998, 102:531-537.

47. Zhao $X$, Chen FP, Sullender WM: Respiratory syncytial virus escape mutant derived in vitro resists palivizumab prophylaxis in cotton rats. Virology 2004, 318:608-612.

48. Zhao X, Liu E, Chen FP, Sullender WM: In Vitro and In Vivo Fitness of Respiratory Syncytial Virus Monoclonal Antibody Escape Mutants. I Virol 2006, 80(23):11651-11657.

49. Cardenas S, Auais A, Piedimonte G: Palivizumab in the prophylaxis of respiratory syncytial virus infection. Expert Rev Anti Infect Ther 2005, 3:719-726

50. Everitt DE, Davis CB, Thompson K, DiCicco R, Ilson B, Demuth SG, Herzyk DJ, Jorkasky DK: The pharmacokinetics, antigenicity, and fusion-inhibition activity of RSHZ19, a humanized monoclonal antibody to respiratory syncytial virus, in healthy volunteers. J Infect Dis 1996, 174:463-469.

51. Chen MD, Vazquez M, Buonocore L, Kahn JS: Conservation of the respiratory syncytial virus SH gene. J InfecT Dis 2000, 182:1228-1233.

52. Bukreyev A, Whitehead SS, Murphy BR, Collins PL: Recombinant respiratory syncytial virus from which the entire SH gene has been deleted grows efficiently in cell culture and exhibits site-specific attenuation in the respiratory tract of the mouse. J Virol 1997, 71(12):8973-8982.

53. Ferron F, Longhi S, Henrissat B, Canard B: Viral RNA polymerases - a predicted 29-O-ribose methyltransferase domain shared by all Mononegavirales. Trends Biochem Sci 2002, 27:222-224.

54. Poch O, Blumberg BM, Bougueleret $\mathrm{L}$, Tordo $\mathrm{N}$ : Sequence comparison of five polymerases ( $L$ proteins) of unsegmented negative-strand RNA viruses: theoretical assignment of functional domains. J Gen Virol 1990, 71:1153-1162.

55. Hardy RW, Wertz GW: The Cys(3)-His(1) motif of the respiratory syncytial virus M2-1 protein is essential for protein function. $J$ Virol 2000 74(13):5880-5885.

56. Tang RS, Nguyen N, Cheng $X$, Jin H: Requirement of cysteines and length of the human respiratory syncytial virus M2-1 protein for protein function and virus viability. J Virol 75(23):11328-11335.

57. Ahmadian $G$, Chambers $P$, Easton AJ: Detection and characterization of proteins encoded by the second ORF of the M2 gene of pneumoviruses. J Gen Virol 1999, 80:2011-2016.

58. Cheng X, Park HJ, Zhou H, Jin H: Over expression of the M2-2 Protein of Respiratory Syncytial Virus Inhibits Viral Replication. J Virol 2005, 79(22):13943-13952. 
59. Moudy RM, Harmon SB, Sullender WM, Wertz GW: Variations in transcription termination signals of Human respiratory syncytial virus clinical isolates affect gene expression. Virology 2003, 313:250-260.

60. Elliott J, Lynch OT, Suessmuth Y, Qian P, Boyd CR, Burrows JM, Buick R, Stevenson NJ, Touzelet O, Gadina M, Power UF, Johnston JA: Respiratory syncytial virus NS1 protein degrades STAT2 by using the Elongin-Cullin E3 ligase. J Virol 2007, 81(7):3428-3436.

61. Zhang W, Yang H, Kong X, Mohapatra S, Juan-Vergara HS, Hellermann G, Behera S, Singam R, Lockey RF, Mohapatra SS: Inhibition of respiratory syncytial virus infection with intranasal siRNA nanoparticles targeting the viral NS1 gene. Nature Medicine 2004, 11:56-62.

62. McGivern DR, Collins PL, Fearns R: Identification of internal sequences in $3^{\prime}$ leader region of human respiratory syncytial virus that enhance transcription and confer replication processivity. Virology 2005, 79(4):2449-2460

63. Fearns R, Peeples ME, Collins PL: Mapping the Transcription and Replication Promoters of Respiratory Syncytial Virus. J Virol 2002, 76(4):1663-1672.

64. Cowton VM, Fearns R: Evidence that the respiratory syncytial virus polymerase is recruited to nucleotides 1 to 11 at the $3^{\prime}$ end of the nucleocapsid and can scan to access internal signals. J Virol 2005, 79:11311-11322.

65. Kuo L, Fearns R, Collins PL: Analysis of the gene start and gene end signals of human respiratory syncytial virus: Quasi-templated initiation at position 1 of the encoded mRNA. J Virol 1997, 71(7):4944-4953.

66. Harmon $S B$, Megaw AG, Wertz GW: RNA sequences involved in transcriptional termination of respiratory syncytial virus. J Virol 2001, 75(1):36-44.

67. Peeples $\mathrm{M}$, Collins PL: Mutations in the trailer region of a respiratory syncytial virus minigenome which limit RNA replication to one Step. $J$ Virol 2000, 74(1):146-155.

68. Moudy RM, Sullender WM, Wertz GW: Variations in intergenic region sequences of Human respiratory syncytial virus clinical isolates: analysis of effects on transcriptional regulation. Virology 2004, 327:121-133.

69. Villenave $R$, O'Donoghue D, Thavagnanam S, Touzelet O, Skibinski G, Heaney LG, McKaigue JP, Coyle PV, Shields MD, Power UF: Differential cytopathogenesis of respiratory syncytial virus prototypic and clinical isolates in primary pediatric bronchial epithelial cells. Virology Journal 2011, 8:43

70. Radhakrishnan A, Yeo D, Brown G, Myaing MZ, lyer LR, Fleck R, Tan BH, Aitken J, Sanmun D, Tang K, et al: Protein analysis of purified respiratory syncytial virus particles reveals an important role for heat shock protein 90 in virus particle assembly. Mol Cell Proteomics 2010, 9(9):1829-48.

doi:10.1186/1743-422X-8-372

Cite this article as: Kumaria et al: Whole genome characterization of non-tissue culture adapted HRSV strains in severely infected children. Virology Journal 2011 8:372.

\section{Submit your next manuscript to BioMed Central and take full advantage of:}

- Convenient online submission

- Thorough peer review

- No space constraints or color figure charges

- Immediate publication on acceptance

- Inclusion in PubMed, CAS, Scopus and Google Scholar

- Research which is freely available for redistribution

Submit your manuscript at www.biomedcentral.com/submit
Biomed Central 